\title{
SCI-FI FILM INFLUENCE ON THE STUDENTS' INTEREST IN GEOLOGY
}

\section{[VPLYV SCI-FI FILMU NA ZAUJEM STUDENTOV O GEOLOGIU]}

\author{
Jan Stubna
}

doi: 10.18355/PG.2018.7.1.11

\begin{abstract}
Mass media means have an influence on students every day. New technology and innovation are the current trends used in the educational process. Geology is regarded one of the least popular areas of natural sciences by the students. In this paper, we present results of the research in which we were examining the rate of the influence of a sci-fi film dealing with a geological issue on the lesson as regards the students' interest in geology in secondary schools.
\end{abstract}

\section{Key words}

film, geology, innovation, sci-fi

\section{Anotácia}

Masmediálne prostriedky ovplyvňujú študentov každý deň. V súčasnosti je trend vo vyučovacom procese využívat' nové technológie a inovovat' vyučovací proces. Študenti pokladajú geológiu za jednu $z$ najmenej populárnych oblastí prírodovedných predmetov. V príspevku prezentujeme výsledky výskumu, v ktorom sme zist'ovali do akej miery ovplyvnilo sledovanie sci-fi filmu s geologickou tematikou na vyučovacej hodine záujem študentov stredných škôl o geológiu.

\section{Kl’účové slová}

film, geológia, inovácia, sci-fi

\section{Úvod}

Škola by mala rozvíjat' aktivity u študentov a ich túžby po poznaní. Vzt'ah študenta $\mathrm{k}$ učeniu sa odvíja od konkrétnych postojov a vzt’ahov k jednotlivým vyučovacím predmetom. Postoje študenta k jednotlivým učebným predmetom úzko súvisia $\mathrm{s}$ motiváciou študentovej učebnej činnosti (Hrubiskova et. al. 2007). V súčasnosti neustále rastie dôležitost' funkčného a efektívneho prírodovedného vzdelávania jednotlivcov pre život a prácu $\mathrm{v}$ modernej a na poznanie orientovanej spoločnosti. Základným predpokladom je vzdelanost' jednotlivcov v prírodovednej oblasti, aby dokázali v osobnom živote a pri vykonávaní svojej profesie účinne využívat' výdobytky prírodovedného výskumu. Ide predovšetkým o viacodborové vzdelanie, ktoré integruje rôzne prístupy $\mathrm{k}$ prírodovedným objektom a témam (Veselsky, 2010). Vo viacerých výskumoch bolo zistené, že motivácia k štúdiu prírodovedných predmetov ma klesajúcu tendenciu $\mathrm{v}$ priebehu dospievania (Anderman, Young, 1994; Vedder-Weiss, Fortus, 2011). Záujem žiakov a 
študentov o prírodné vedy u nás je pomerne nízky alebo má klesajúcu tendenciu (Veselsky, 1997; Held, 2007).

Motiváciu žiakov učit' sa môžeme špecifikovat' ako dispozíciu žiakov vykonávat' vhodné a hodnotné učebné činnosti a zároveň pokúšat' sa nachádzat' $\mathrm{v}$ nich pre seba nejaký úžitok (Brophy, 2004). Tento prístup $\mathrm{k}$ motivácii je $\mathrm{v}$ súlade $\mathrm{s}$ konštruktivistickou teóriou, ktorá predpokladá kognitívnu zaangažovanost', vynakladanie úsilia, teda motiváciu v procese zmysluplného učenia. $V$ posledných rokoch vel'ké množstvo štúdií prezentuje, že motivácia zohráva dôležitú úlohu $\mathrm{v}$ učení prírodovedných predmetov (Dalgety et. al., 2003; Zusho et. al. 2003; Schlarmannova et. al., 2006; Illasova - Sandanusova, 2006; Tüysüza et. al., 2010).

Existuje niekol'ko spôsobov, ktorými môže učitel' zvýšit' u žiakov motiváciu. Je dôležité napríklad vytvorit' pozitívnu učebnú klímu, zaktivizovat' žiakov na vyučovaní a podnietit' tak ich túžbu po vedomostiach. Jednou z ciest je aj zavedenie alebo obmieňanie metód vyučovania prípadne zavádzanie nových alternatívnych metód výučby (Veselsky, 2005). Ich príkladom sú audiovizuálne metódy ako napríklad premietanie filmov či videosekvencií alebo rôzne formy aktivizujúcich metód. Pre žiakov sú okrem prameňa poznatkov často aj zdrojom potešenia a zábavy. Viaceré štúdie ukazujú, že jedným z úspešných spôsobov, ako zvýšit motiváciu žiakov $\mathrm{k}$ štúdiu prírodovedných predmetov je pomocou integrácie vizualizácie a animácie do vyučovacieho procesu (Barak - Dori 2005; Barak et al 2011). Aplikácia animácií a vizualizácie prispieva študentom ku konceptuálnemu porozumeniu (Barak, Dori 2005), k úspechu v učení (Dori et al 2003,. Dori - Belcher 2005), k priestorovej orientácii (Barnea - Dori, 2000) a motivácii k učeniu sa vedeckých poznatkov (Barak et al., 2011). Použitie filmov ako výučbový materiál má pozitívny vplyv na študentovú motiváciu (Stubna - Vrestiakova, 2008; Hostovecky et.al., 2012).

Zist'ovanie vplyvu dynamickej projekcie na motiváciu žiakov bolo predmetom výskumu v roku 2010 v Izraeli. Ciel'om tohto výskumu bolo zistit' v akej miere ovplyvňuje dynamická projekcia motiváciu žiakov štvrtého a piateho ročníka základných škôl. Učitelia vytvorili pre svojich žiakov webovú stránku, na ktorej sa nachádzali niekol'ko minútové videá, ktoré zábavným spôsobom vysvetl'ovali stovky teoretických vedeckých konceptov. Takáto projekcia im bola premietaná minimálne jedenkrát týždenne a vždy súvisela s aktuálnym učivom. Po skončení výskumu žiaci vykazovali značný pokrok týkajúci sa sebahodnotenia, zmien v postojoch a ich záujmoch. Často sa vyjadrovali o dôležitosti vedy pre človeka a jej prepojenosti s každodenným životom. Film teda značne zvýšil ich vnútornú motiváciu a prehíbil záujem o prírodné javy aj vedu samotnú (Barak et al., 2011). Samotný film je teda okrem priameho využitia pri konkrétnych učivách vel'mi vhodný aj na podnietenie diskusií o kontroverzných témach. Žiaci môžu takýmto spôsobom spájat' vedu s potenciálnou realitou, čo ich vedie $\mathrm{k}$ motivácii zaoberat' sa vedeckými faktami a ich vplyvom na človeka aj spoločnost' (Rose, 2007). Preto sme si za ciel' príspevku stanovili, či jednorazové sledovanie filmu dokáže pozitívne ovplyvnit' postoj ku geológii. 


\section{Použité metódy}

Pre naplnenie ciel'a článku vychádzame zo zistenia dotazníkového výskumu. Výskum sme urobili v mesiacoch január až apríl v roku 2014 na vzorke 26 študentov prvého ročníka gymnázia. Po prebratí tematického celku venovaného stavbe Zeme na hodinách geografie, sme študentov nechali sledovat' sci-fi film Jadro. Po mesiaci od sledovania filmu, sme študentom zadali dotazník, ktorý slúžil na zistenie vplyvu sci-fi filmu na záujem študentov o neživú prírodu. Dotazník sme upravili na podmienky použitia jedného filmu z výskumu Laprise, Winrich (2010). Dotazník bol anonymný, mal 8 položiek a odpovede boli zaznamenané na 5 bodovej Likertovej škále. Na zistenia závislosti jednotlivých položiek sme získané údaje zapisovali do kontingenčných tabuliek. Preukaznost' jednotlivých závislostí položiek sme testovali pomocou Pearsonovho chí-kvadrát testu.

\section{Výsledky a diskusia}

Preukazné výsledky hodnoty Pearsonovho chí kvadrát testu $(p>0,05)$ sme zaznamenali v piatich prípadoch:

1) „Páčilo sa mi sledovanie filmu Jadro na hodine.“ a „Učivo bolo zaujímavejšie, ked' sme sledovali aj film.“;

2) „Páčilo sa mi sledovanie filmu Jadro na hodine“ a „Myslím si, že používanie sci-fi filmov na hodinách je užitočné.“;

3) „Sledovanie filmu Jadro mi pomohlo pochopit’ učivo o stavbe Zeme.“ a „Diskusia so spolužiakmi po filme Jadro mi pomohla, aby som lepšie pochopil/a učivo o stavbe Zeme.";

4) „Sledovanie filmu Jadro mi pomohlo pochopit' učivo o stavbe Zeme.“ a „Po zhliadnutí filmu Jadro, som sa začal/a viac zaujímat' o vedu.“;

5) „Diskusia so spolužiakmi po filme Jadro mi pomohla, aby som lepšie pochopil/a učivo o stavbe Zeme.“ a „Po zhliadnutí filmu Jadro, som sa začal/a viac zaujímat' o vedu.".

Tabul'ka 1 Hodnoty Pearsonovho chí-kvadrát testu pre položky, pri ktorých boli preukazné výsledky

\begin{tabular}{|l|c|c|c|c|c|}
\hline & \multicolumn{5}{|c|}{ položky } \\
\hline & 1 a 6 & 1 a 8 & 3 a 4 & 3 a 7 & 4 a 7 \\
\hline $\begin{array}{l}\text { chí- } \\
\text { kvadrát }\end{array}$ & 15,6684 & 16,4752 & 22,1578 & 26,3644 & 32,8756 \\
\hline $\begin{array}{l}\text { stupeň } \\
\text { vol'nosti }\end{array}$ & 6 & 6 & 12 & 16 & 12 \\
\hline
\end{tabular}

V prvom prípade študenti pozitívne vyjadrovali svoj postoj k tomu, že počas vyučovacieho procesu mali možnost' sledovat' film a pokladajú tým vyučovaciu hodinu geografie za zaujímavejšiu. V druhom prípade študenti okrem toho, že pozitívne hodnotia sledovanie filmu, pokladajú túto formu vzdelávania aj za užitočnú. V tret’om prípade študenti vyjadrili nesúhlasné stanovisko, že by im film pomohol pochopit' učivo a zároveň podnietil $\mathrm{k}$ diskusii o filme. V štvrtom prípade informácie $\mathrm{z}$ filmu nepomohli k pochopeniu učiva a taktiež sa študenti nezačali viac zaujímat' o vedu. 
V poslednom piatom prípade tým, že film nepodnietil k diskusii žiakov, výsledkom nebola očakávaná zmena postoja k záujmu o vedu.

Tabul'ka 2 Kontingenčná tabul'ke pre odpovede pre položky v dotazníku 1 a 6

\begin{tabular}{|c|c|c|c|c|c|c|}
\hline \multirow[t]{2}{*}{ Položka 1} & \multicolumn{5}{|c|}{ Položka 6} & \multirow{2}{*}{$\begin{array}{c}\text { položka } \\
1 \\
\text { Spolu }\end{array}$} \\
\hline & $\begin{array}{c}\text { Úplne } \\
\text { súhlasí } \\
\text { m }\end{array}$ & $\begin{array}{c}\text { súhlasí } \\
\mathrm{m}\end{array}$ & $\begin{array}{c}\text { neutráln } \\
\mathrm{e}\end{array}$ & $\begin{array}{c}\text { nesúhlasí } \\
\mathrm{m}\end{array}$ & $\begin{array}{c}\text { úplne } \\
\text { nesúhlasí } \\
\text { m }\end{array}$ & \\
\hline $\begin{array}{c}\text { úplne } \\
\text { súhlasím }\end{array}$ & 9 & 5 & 1 & 0 & 0 & 15 \\
\hline Súhlasím & 6 & 1 & 0 & 0 & 0 & 7 \\
\hline Neutrálne & 0 & 1 & 2 & 1 & 0 & 4 \\
\hline $\begin{array}{c}\text { Nesúhlasí } \\
\mathrm{m}\end{array}$ & 0 & 0 & 0 & 0 & 0 & 0 \\
\hline $\begin{array}{c}\text { úplne } \\
\text { nesúhlasím }\end{array}$ & 0 & 0 & 0 & 0 & 0 & 0 \\
\hline $\begin{array}{c}\text { položka } 6 \\
\text { Spolu }\end{array}$ & 15 & 7 & 3 & 1 & 0 & 26 \\
\hline
\end{tabular}

Tabul'ka 3 Kontingenčná tabul'ke pre odpovede pre položky v dotazníku

\begin{tabular}{|c|c|c|c|c|c|c|}
\hline \multirow[t]{2}{*}{ Položka 1} & \multicolumn{5}{|c|}{ Položka 8} & \multirow{2}{*}{$\begin{array}{c}\text { položk } \\
\text { a } 1 \\
\text { Spolu } \\
\end{array}$} \\
\hline & $\begin{array}{l}\text { úplne } \\
\text { súhlasí } \\
\text { m }\end{array}$ & $\begin{array}{c}\text { súhlasí } \\
\text { m }\end{array}$ & $\begin{array}{c}\text { neutráln } \\
\mathrm{e}\end{array}$ & $\begin{array}{c}\text { nesúhlasí } \\
\mathrm{m}\end{array}$ & $\begin{array}{c}\text { úplne } \\
\text { nesúhlasí } \\
\text { m }\end{array}$ & \\
\hline $\begin{array}{c}\text { úplne } \\
\text { súhlasím }\end{array}$ & 11 & 3 & 1 & 0 & 0 & 15 \\
\hline Súhlasím & 3 & 2 & 2 & 0 & 0 & 7 \\
\hline Neutrálne & 0 & 0 & 3 & 1 & 0 & 4 \\
\hline Nesúhlasím & 0 & 0 & 0 & 0 & 0 & 0 \\
\hline $\begin{array}{c}\text { úplne } \\
\text { nesúhlasím }\end{array}$ & 0 & 0 & 0 & 0 & 0 & 0 \\
\hline $\begin{array}{c}\text { položka } 8 \\
\text { Spolu }\end{array}$ & 14 & 5 & 6 & 1 & 0 & 26 \\
\hline
\end{tabular}

Tabul'ka 4 Kontingenčná tabul'ke pre odpovede pre položky v dotazníku 3 a 4

\begin{tabular}{|c|c|c|c|c|c|c|}
\hline \multirow[t]{2}{*}{ Položka 3} & \multicolumn{5}{|c|}{ Položka 4} & \multirow[t]{2}{*}{$\begin{array}{c}\text { položk } \\
\text { a } 3\end{array}$} \\
\hline & $\begin{array}{l}\text { úplne } \\
\text { súhlasí } \\
\text { m }\end{array}$ & $\begin{array}{c}\text { súhlasí } \\
\text { m }\end{array}$ & $\begin{array}{c}\text { neutráln } \\
\mathrm{e}\end{array}$ & $\begin{array}{c}\text { nesúhlasí } \\
\text { m }\end{array}$ & $\begin{array}{c}\text { úplne } \\
\text { nesúhlasí } \\
\text { m }\end{array}$ & \\
\hline $\begin{array}{c}\text { Úplne } \\
\text { súhlasím }\end{array}$ & 1 & 0 & 0 & 0 & 1 & 2 \\
\hline Súhlasím & 0 & 0 & 0 & 1 & 4 & 5 \\
\hline Neutrálne & 0 & 0 & 2 & 6 & 2 & 10 \\
\hline Nesúhlasím & 0 & 0 & 0 & 3 & 3 & 6 \\
\hline
\end{tabular}

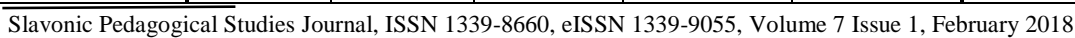




\begin{tabular}{|c|c|c|c|c|c|c|}
$\begin{array}{c}\text { úplne } \\
\text { nesúhlasím }\end{array}$ & 0 & 0 & 1 & 0 & 2 & 3 \\
\hline $\begin{array}{c}\text { položka 4 } \\
\text { Spolu }\end{array}$ & 1 & 0 & 3 & 10 & 12 & 26 \\
\hline
\end{tabular}

Tabul'ka 5 Kontingenčná tabul'ke pre odpovede pre položky v dotazníku 3 a 7

\begin{tabular}{|c|c|c|c|c|c|c|}
\hline \multirow[t]{2}{*}{ Položka 3} & \multicolumn{5}{|c|}{ Položka 7} & \multirow{2}{*}{$\begin{array}{c}\text { položk } \\
\text { a } 3 \\
\text { Spolu } \\
\end{array}$} \\
\hline & $\begin{array}{c}\text { úplne } \\
\text { súhlasí } \\
\text { m }\end{array}$ & $\begin{array}{c}\text { Súhlasí } \\
\mathrm{m}\end{array}$ & $\begin{array}{c}\text { neutráln } \\
\mathrm{e}\end{array}$ & $\begin{array}{c}\text { nesúhlasí } \\
\text { m }\end{array}$ & $\begin{array}{c}\text { úplne } \\
\text { nesúhlasí } \\
\text { m }\end{array}$ & \\
\hline $\begin{array}{l}\text { úplne } \\
\text { súhlasím }\end{array}$ & 1 & 0 & 1 & 0 & 0 & 2 \\
\hline Súhlasím & 0 & 0 & 1 & 3 & 1 & 5 \\
\hline Neutrálne & 0 & 0 & 2 & 2 & 6 & 10 \\
\hline $\begin{array}{c}\text { Nesúhlasí } \\
\mathrm{m}\end{array}$ & 0 & 1 & 0 & 0 & 5 & 6 \\
\hline $\begin{array}{c}\text { úplne } \\
\text { nesúhlasím }\end{array}$ & 0 & 0 & 1 & 1 & 1 & 3 \\
\hline $\begin{array}{c}\text { položka } 7 \\
\text { Spolu }\end{array}$ & 1 & 1 & 5 & 6 & 13 & 26 \\
\hline
\end{tabular}

Tabul'ka 6 Kontingenčná tabul'ke pre odpovede pre položky v dotazníku

4 a 7

\begin{tabular}{|c|c|c|c|c|c|c|}
\hline \multirow[t]{2}{*}{ Položka 4} & \multicolumn{5}{|c|}{ Položka 7} & \multirow{2}{*}{$\begin{array}{c}\text { položka } \\
4 \\
\text { Spolu }\end{array}$} \\
\hline & $\begin{array}{l}\text { úplne } \\
\text { súhlasím }\end{array}$ & Súhlasím & neutrálne & nesúhlasím & $\begin{array}{c}\text { úplne } \\
\text { nesúhlasím }\end{array}$ & \\
\hline $\begin{array}{l}\text { úplne } \\
\text { súhlasím }\end{array}$ & 1 & 0 & 0 & 0 & 0 & 1 \\
\hline Súhlasím & 0 & 0 & 0 & 0 & 0 & 0 \\
\hline Neutrálne & 0 & 0 & 0 & 2 & 1 & 3 \\
\hline Nesúhlasím & 0 & 1 & 1 & 2 & 6 & 10 \\
\hline $\begin{array}{c}\text { Úplne } \\
\text { nesúhlasím }\end{array}$ & 0 & 0 & 4 & 2 & 6 & 12 \\
\hline $\begin{array}{c}\text { položka } 7 \\
\text { Spolu }\end{array}$ & 1 & 1 & 5 & 6 & 13 & 26 \\
\hline
\end{tabular}

\section{Záver}

Ciel'om príspevku bolo, či je možné pomocou filmu (jednorázovo) vytvorit' u študentov pozitívny postoj ku geológii. Vo výsledkoch nášho experimentu sme nenašli relevantné dôkazy toho, že jednorazové zavedenie filmu do vyučovacieho procesu, by zmenilo celkový postoj študentov ku geológii, aj ked’ pre experiment bol vybraný film, ktorý spĺn̆al parametre „,blockbusteru“. Študenti síce vyjadrili záujem o film a hodinu geografie (so zameraním na geológiu) pokladali za zaujímavejšiu, ale film ich nezaujal do takej miery, že by u nich podnietil diskusiu, prípadne zvýšil záujem o geológiu.

Tento článok vznikol vd’aka projektu KEGA 062UKF-4/2016.

\section{Bibliographic references}


ANDERMAN, E. M. - YOUNG, A. J. 1994. Motivation and Strategy Use in Science - Individual-Differences and Classroom Effects. In Journal of Research in Science Teaching, vol. 31, no. 8, pp. 811-831.

BARAK, M. - DORI, Y. J. 2005. Enhancing undergraduate students' chemistry understanding through project-based learning in an IT environment. In Science Education, vol. 89, no. 1, pp. 117-139.

BARAK, M. et al. 2011. Learning science via animated movies: Its effect on students' thinking and motivation. In Computers \& Education, vol. 56, No. 3, pp. 839-846.

BARNEA, N. - DORI, Y. J. 2000. Computerized molecular modeling the new technology for enhancing model perception among chemistry educators and learners. In Chemistry Education: Research and Practice in Europe, vol. 1 , no. 1 , pp. 109-120.

DALGETY, J. et al. 2003. The development of the chemistry attitudes and experiences questionnaire (CAEQ). In Journal of Research in Science Teaching, vol. 40, no. 7, pp. 649-668.

DORI, Y. J. - BELCHER, J. W. 2005. How does technology-enabled active learning affect students' understanding of scientific concepts? In The Journal of the Learning Sciences, vol. 14, no. 2, pp. 243-279.

DORI, Y. J. et al. 2003. A web-based chemistry course as a means to foster freshmen learning. In Journal of Chemical Education, vol. 80, no. 9, pp. 1084-1092.

HELD, L. 2007. The education that supports science, research and inovations (The situation of the science education in Trnava region as a precondition for the use of science in social and manufactural practice). In Acta Faculty Paedagogicae Universitatis Tyrnaviensis, Ser. D, no. 11, pp. 16-35.

HOSTOVECKY, M. et al. 2012. The potential implementation of 3D technology in science education. In ICETA 2012, Stara Lesna, Slovakia. Danvers : Copyright Clearance Center, 2012. pp. 135-138.

HRUBISKOVA, H. et al. 2007. Motivation to study biology of students attending grammar school and its intuitive diagnostic by the teacher. In Aktualne trendy vo vyucovani prirodovednych predmetov. Bratislava : Sevt, 2007. p. $105-108$.

ILLASOVA, L. - SANDANUSOVA, A. 2006. Vyuzitie vysledkov vyskumu $\mathrm{v}$ edukacnom procese. In Vyzkum $\mathrm{v}$ oborovych didaktikach prirodovednych, zemedelskych a pribuznych oboru, Praha: PF UK, 2006, s. 146-151.

ROSE, CH. S. 2007. Biology in the movies: Using the Double-Edged Sword of Popular Culture to Enhance Public Understanding of Science. In Evolutionary Biology, vol. 34, No. 1-2, pp. 49-54.

SCHLARMANOVA, J. et al. 2006. Vyucovacia hodina trochu inak. In Metody, formy, a prostredky pro vyuku prirodovednych, zemedelskych a pribuznych oboru, Praha: PF UK, 2006, s. 92-94.

STUBNA, J. - VRESTIAKOVA, L. 2008. Analyzy prirodopisnych filmov z hladiska dostupnosti roznych audiovizualnych prostriedkov pre vyucovanie prirodovednych predmetov. In Paidagogos casopis pro pedagogiku a s ni souvisejici vedy. [online]. c. 2-3 [cit. 2016-02-03]. Available online: www.paidagogos.net . 
TUYSUZA, M. et al. 2010. What is the motivation difference between university students and high school students? In Procedia Social and Behavioral Sciences, vol. 2, no. 2, pp. 1543-1548

VEDDER-WEISS, D. - FORTUS, D. 2011. Adolescents' Declining Motivation to Learn Science: Inevitable or Not? In Journal of Research in Science Teaching, vol. 48, no. 2, pp. 199-216

VESELSKY, M. 2010. Motivacia ziakov ucit sa. Bratislava : Univerzita Kokemskeho, 2010. 116 pp.

VESELSKY, M. 2005. Pedagogicka psychologia 2. Bratislava : Univerzita Komenskeho, 2005. 168 pp.

VESELSKY, M. 1997. Postoje a pripomienky ziakov 1. rocnikov gymnazia, strednych odbornych skol a ucilist k obsahu ucebneho predmetu chemia na zakladnej skole. In Biologia, ekologia, chemia, vol. 2, no. 2, pp. 24-25.

ZUSHO, A. et al. 2003. Skill and will: The role of motivation and cognition in the learning of college chemistry. In International Journal of Science Education, vol. 25, no. 9, pp. 1081-1094.

PaedDr. Ján Štubňa, PhD.

Institute of Geology

Faculty of Natural Sciences

Constantine the Philosopher University in Nitra

Tr. A. Hlinku 1, 94901 Nitra

Slovakia

janstubna@gmail.com 